Abstracta Iranica Abstracta Iranica

Revue bibliographique pour le domaine irano-aryen

Volume 26 | 2005

Comptes rendus des publications de 2003

Visions of Persia: Mapping the Travels of Adam Olearius. Harvard University Press, 2003, xv-238 p., bibliography, index.

Rudi Matthee

OpenEdition

Journals

Édition électronique

URL : http://journals.openedition.org/abstractairanica/2739

ISSN : 1961-960X

Éditeur :

CNRS (UMR 7528 Mondes iraniens et indiens), Éditions de l'IFRI

Édition imprimée

Date de publication : 15 mai 2005

ISSN : 0240-8910

Référence électronique

Rudi Matthee, "Visions of Persia: Mapping the Travels of Adam Olearius. Harvard University Press, 2003, xv-238 p., bibliography, index. », Abstracta Iranica [En ligne], Volume 26 | 2005, document 220, mis en ligne le 08 décembre 2005, consulté le 25 septembre 2020. URL : http://journals.openedition.org/ abstractairanica/2739

Ce document a été généré automatiquement le 25 septembre 2020.

Tous droits réservés 


\title{
Visions of Persia: Mapping the Travels of Adam Olearius. Harvard University Press, 2003, xv-238 p., bibliography, index.
}

\author{
Rudi Matthee
}

1 This fascinating study of the work of Adam Olearius, the secretary of the Holstein embassy that visited Iran in 1636-37, is primarily concerned with the author as a man of letters and the tradition in which he operated, as well as with the dialogue between text and image in his well-known Vermehrte newe Beschreibung der Moscowitischen und Persischen Reyse. As such it only deals tangentially with Iran or the extent of the work's veracity and reliability as a source. Olearius is the quintessential baroque work reflecting the court of the Frederic of Gottorp, a quintessentially baroque ruler with ambitions to greatness. As the author explains, Olearius's work represents a transitional phase in being multifaceted. Deeply imbued with classical and Renaissance notions, his account also is experimental and experiential and as such constitutes more an ethnology of the lands he traversed than a geographical study. His work makes full use of the theatrical possibility of the illustration.

Chapter one is a learned disquisition on the frontispiece, seen here as a portal into the text that follows, its development and the meaning of its often allegorical imagery. The frontispiece remains central in chapter three which discusses Olearius as translator of Sa'di's Gulistan, relying heavily on Faramarz Behzad's 1970 study of Olearius' translation. The appearance of a lion leads the author to discuss the symbolism of this animal in the Iranian tradition, and the appearance of lion skins in illustrations prompts him to look for models in Rubens and contemporary travelogues. Chapter four, Olearius as cartographer, focuses on the traveler's dense map of Iran and in particular his rendering of the Caspian Sea, with particular emphasis on the graphic signs and the pictorial icons. Based on personal observations, Olearius's map of the Caspian represents a new level of realism and sophistication inasmuch as it was the 
first realistic cartographic rendering of the area since Ptolemy. Careful comparison of measurements leads the author to speculate that Olearius may have been familiar with the works of some of the classic Islamic geographers.

INDEX

Thèmes : 4.2.1. Safavides et Qâjârs

\section{AUTEURS}

RUDI MATTHEE

University of Delaware 